\title{
Analisis disparitas pendapatan di Indonesia tahun 2015- 2019: analisis regresi data panel
}

\author{
Niken Ningtiyas, Inayati Nuraini Dwiputri* \\ Universitas Negeri Malang, Jl. Semarang No. 5 Malang, Jawa Timur, Indonesia \\ *Penulis korespondensi, Surel: inayati.dwiputri.fe@um.ac.id
}

Paper received: 5-7-2021; revised: 23-7-2021; accepted: 30-7-2021

\begin{abstract}
Income disparity is a problem in many countries that can cause economic inefficiency, weaken social stability and solidarity, and inequality in long-term well-being. This study describes the income disparity in the provinces in Indonesia using the Williamson Index. The purpose of this study is to find out how the conditions of income disparity in Indonesia are and what are the variables that influence it. This study analyzes panel data regression from 32 provinces in Indonesia for 5 years through Eviews10. From the Williamson index calculation, East Java Province has the highest level of disparity while Gorontalo Province has the lowest disparity. Economic growth, investment, APBD, and Unemployment have a positive effect on income disparity while HDI has a negative effect. Variables that have a significant effect on the 5 percent alpha level are HDI, Government Spending, and Unemployment. While the variable of economic growth has a prob of 0.1558 so that it has a significant effect on income disparities at the alpha level of 0.2 or 20 percent, and investment has a prob of 0.4570 so that it has a significant effect on the alpha level of 0.5 or 50 percent.
\end{abstract}

Keywords: income disparity; williamson index; Indonesia

\begin{abstract}
Abstrak
Disparitas pendapatan merupakan suatu permasalahan di banyak negara yang dapat menyebabkan inefisiensi ekonomi, melemahkan stabilitas sosial dan solidaritas, serta ketidakadilan dalam kesejahteraan dalam jangka panjang. Penelitian ini menggambarkan disparitas pendapatan di provinsi-provinsi di Indonesia dengan Indeks Williamson. Tujuan dari penelitian ini adalah untuk mengetahui bagaimana kondisi disparitas pendapatan di Indonesia dan apa saja variabel-variabel yang mempengaruhinya. Penelitian ini menganalisis regresi data panel dari 32 provinsi di Indonesia selama 5 tahun melalui Eviews10. Dari perhitungan indeks williamson, Provinsi jawa timur memiliki tingkat disparitas tertinggi sementara Provinsi Gorontalo memiliki disparitas terendah. Pertumbuhan ekonomi, investasi, APBD, dan TPT berpengaruh positif terhadap disparitas pendapatan sedangkan IPM berpengaruh negatif. Variabel yang berpengaruh signifikan pada tingkat alpha 5 persen yakni IPM, APBD, dan TPT. Sedangkan variabel pertumbuhan ekonomi memiliki prob sebesar 0.1558 sehingga berpengaruh signifikan terhadap disparitas pendapatan pada tingkat alpha 0.2 atau 20 persen, dan investasi memiliki prob sebesar 0.4570 sehingga berpengaruh signifikan pada tingkat alpha 0.5 atau 50 persen.
\end{abstract}

Kata kunci: disparitas pendapatan; indeks williamson; Indonesia

\section{Pendahuluan}

Pembangunan ekonomi wilayah merupakan suatu proses yang dilakukan untuk meningkatkan kesejahteraan, mengurangi tingkat pengangguran serta menekan ketimpangan antar wilayah. Salah satu faktor keberhasilan pembangunan di suatu negara adalah dengan adanya pemerataan pembangunan. Pemerataan pembangunan bukanlah perkara mudah, dilihat dari banyaknya hal yang harus dipenuhi agar tercapainya suatu kesejahteraan dan pembangunan yang merata. Hidayat (2014) pembangunan ekonomi suatu negara dinyatakan berhasil jika terjadinya pertumbuhan ekonomi dan diiringi oleh berkurangnya ketimpangan

This work is licensed under a Creative Commons Attribution-ShareAlike 4.0 International License. 
pendapatan. Di Indonesia, upaya pemerintah dalam mengurangi disparitas pendapatan selain melalui kebijakan otonomidaerah, namun juga telah tertuang dalam RPJMN 2019-2024 yang berupaya mengentaskan permasalahan ketimpangan dalam mewujudkan pemerataan pembangunan ke seluruh masyarakat melalui pengembangan wilayah dengan menggunakan dua strategi utama yakni strategi pertumbuhan dan strategi pemerataan.

Salah satu indikator dalam keberhasilan pembangunan ekonomi adalah pertumbuhan ekonomi, berikut merupakan perkembangan pertumbuhan ekonomi pada provinsi-provinsi di Indonesia.

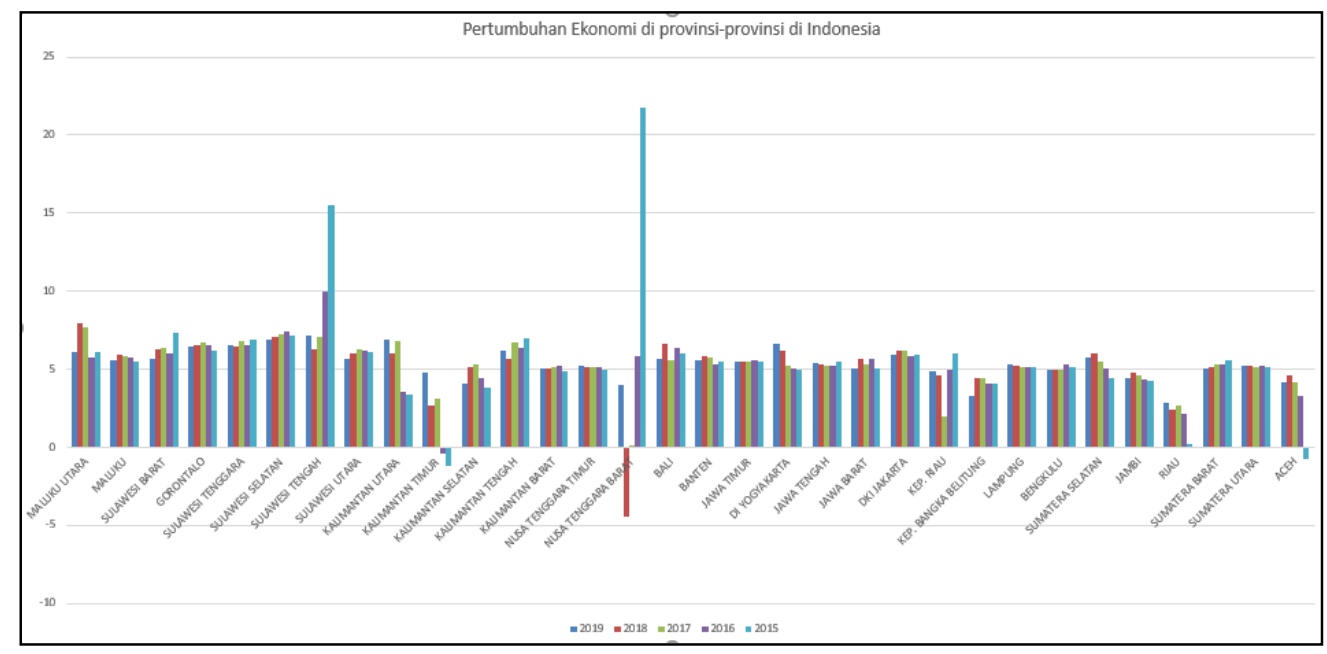

Gambar 1. Perkembangan Pertumbuhan Ekonomi di Indonesia

Sumber: Data diolah(2021)

Meningkatkan pertumbuhan PDRB yang tinggi untuk melakukan pembangunan ekonomi akan memiliki konsekuensi apabila tidak diimbangi dengan upaya menciptakan pemerataan distribusi pendapatan. Hal ini nantinya akan menimbulkan sebuah masalah baru yang biasa disebutdengan ketimpangan pendapatan. Menurut Kuznets, distribusi pendapatan akan lebih merata ketika pertumbuhan ekonomi di suatu wilayah tersebut sudah berada di tahap yang lebih matang, danmemang pada awal pertumbuhan, menurut Kuznets distribusi pendapatan akan cenderung tidak merata.

Disparitas atau ketimpangan pendapatan merupakan suatu kondisi dimana pendapatan antardaerah masih memiliki selisih yang signifikan dan dalam jangka panjang hal ini akan menjadi permasalahan yang serius mengingat tujuan dari suatu negara adalah kesejahteraan masyarakatnya secara merata. Ketimpangan distribusi pendapatan memanglah berhubungan erat dengan pembangunan ekonomi itu sendiri, sehingga diperlukan strategi supaya pertumbuhan yang ingin dicapai juga dapat dibarengi dengan pemerataan pula dan juga menjaga ketidakmerataan yang terjadi tidak semakin tinggi. Oleh karena itu jika ketimpangan pendapatan dibiarkan terus meninggi dan tidak segera diatasi akan menimbulkan berbagai masalah yang kompleks seperti tingginya angka kemiskinan, tingkat kesejahteraan masyarakat yang rendah. Ketimpangan pendapatan perlu penanganan yang serius agar tingkat ketimpangannya rendah dan terkontrol. Sehingga kebijakan pembangunan dapat terlaksana dengan baik dan kesejahteraan masyarakat akan lebih dekat dengankeberhasilan. 
Sementara itu, studi lainnya menganalisis disparitas pendapatan melalui faktor-faktor yang mempengaruhinya. Lilis (2012) menyebutkan disparitas pendapatan umumnya terjadi pada setiap negara dan setiap daerahnya dikarenakan perbedaan potensi sumber daya alam yang tersedia, perbedaan keberadaan investasi dalam mengolah sumber daya alamnya, serta perbedaan kebijakan pemerintah pusat yang mengutamakan daerah tertentu dalam perencanaan yang menjadikan pertumbuhan ekonomi masing-masing daerah juga berbeda beda. Selain itu, faktor IPM juga mempengaruhi disparitas pendapatan dari sisi sumber daya manusianya. Karena dengan tingkat IPM yang tinggi maka kualitas SDM pada suatu daerah akan semakin tinggi dan akan berperan dalam pengurangan disparitas pendapatan baik secara langsung maupun tidak langsung. Selain itu faktor yang mempengaruhi yaitu adanya tingkat pengangguran terbuka, TPT yang tinggi diasumsikan akan membebani suatu daerah dan menjadi penyumbang dalam disparitas pendapatan. Selain itu, ketimpangan antar daerah pada umumnya bisa terjadi dalam proses pembangunan daerah juga dikarenakan faktor lain seperti perbedaan potensi sumber daya alam, sumber daya manusia, arus modal, kebijakan pembangunan pemerintah pusat yang kurang menguntungkan wilayah tertentu dan perencanaan daerah yang kurang tepat, Lilis (2012).Beberapa gap penelitian tentang analisis disparitas pendapatan dan faktor faktor penyebabnya inilah yang menyebabkan perlunya studi tentang disparitas pendapatan serta variabel apa saja yang mempengaruhinya agar disparitas pendapatan segera terwujud dan pemerataan kesejahteraan segera tercapai.

\subsection{TINJAUAN PUSTAKA}

\subsubsection{Konsep Pembangunan Ekonomi}

Pembangunan ekonomi merupakan perubahan mendasar atas struktur sosial, sikap masyarakat, lembaga nasional, percepatan pertumbuhan ekonomi dengan tetap memperhatikan pengurangan ketimpangan dan pengentasan kemiskinan. Menurut Todaro (2006) pembangunan ekonomi memiliki tiga tujuan utama yakni: (1) Peningkatan ketersediaan serta perluasan distribusi berbagai barang kebutuhan yang pokok. (2) Peningkatan standar hidup berupa penambahan penyediaan lapangan kerja, perbaikan kualitas pendidikan, serta peningkatan perhatian atas nilai-nilai kultural dan kemanusiaan. (3) Perluasan pilihan-pilihan ekonomis dan sosial bagi setiap individu serta bangsa secara keseluruhan

\subsubsection{Konsep Pertumbuhan Ekonomi}

Boediono (2000) menyatakan bahwa pertumbuhan ekonomi menjelaskan mengenai faktor-faktor apa saja yang dapat menentukan kenaikan output perkapita dalam jangka panjang, dan penjelasan mengenai bagaimana faktor-faktor yang mempengaruhi tersebut dapat mendorong suatuproses pertumbuhan. Disamping itu, menurut Levine dan Renelt dalam Inayati (2020) salah satu halyang mempengaruhi pertumbuhan ekonomi adalah investasi, sementara menurut Dreher dan Gassebner dalam Inayati (2020) menyebutkan bahwa aktivitas kewirausahaan berpengaruh terhadappertumbuhan ekonomi.

Teori pertumbuhan ekonomi endogen atau sering disebut dengan teori pertumbuhan baru (new growth theory), merupakan suatu teori yang menyajikan suatu kerangka teoritis untuk menganalisis pertumbuhan endogen atau proses pertumbuhan Gross National Product (GNP) yangbersumber dari suatu sistem yang mengatur proses produksi. Teori pertumbuhan endogen (endogenous growth theory) muncul dikarenakan kinerja teori neoKlasik yang tidak memuaskan dalam menjelaskan sumber-sumber pertumbuhan ekonomi jangka panjang. Teori 
pertumbuhan ekonomi endogen menyatakan bahwa pertumbuhan GNP itu sebenarnya merupakan suatu konsekuensi alamiah atas adanya ekuilibrium jangka panjang (Todaro, 1994). Todaro juga menjelaskan bahwa melalui model pertumbuhan endogen dapat diketahui bahwa potensi keuntungan investasi yang tinggi di negara-negara berkembang yang rasio modal tenaga kerjanya masih rendah, ternyata terkikis oleh rendahnya tingkat investasi komplementer (complementary investment) dalam modal atau sumber daya manusia (terutama melalui pengembangan fasilitas dan lembaga pendidikan), sarana-sarana infrastruktur, serta aneka kegiatan penelitian dan pengembangan. Model ini menganjurkan keikutsertaan pemerintah secara aktif dalam pengelolaan perekonomian nasional demi mempromosikan pembangunan ekonomi melalui investasi langsung dan tidak langsung dalam pembentukan modal manusia dan mendorong investasi swasta asing dalam industri padat teknologi (Todaro, 1994).

\subsubsection{Konsep Disparitas Pendapatan}

Disparitas atau ketimpangan pendapatan merupakan suatu keadaan dimana pendapatan antar wilayah masih memiliki selisih yang signifikan dan dalam jangka panjang dapat berdampak buruk bagi perekonomian. Todaro (2006) menyebutkan bahwa disparitas pendapatan selain memiliki dampak positif yang mendorong dan memotivasi daerah tertinggal untuk mengejar ketertinggalannya, juga memiliki dampak negatif berupa inifiensi ekonomi, melemahkan stabilitas sosial dan solidaritas, serta ketidakadilan dalam kesejahteraan. Menurut Williamson pada tahap awal pembangunan ekonomi terdapat kesenjangan kemakmuran antar daerah, namun semakin maju pembangunan ekonomi kesenjangan tersebut semakin menyempit. Hal ini sesuai dengan pendapat Kuznet yang menyatakan bahwa dalam jangka pendek terdapat korelasi positif antara pertumbuhan pendapatan perkapita dengan ketimpangan pendapatan, sebaliknya dalam jangka panjang hubungan keduanya menjadi korelasi yang negatif. Observasi ini yang sering dikenal dengan hipotesis "Uterbalik" Kuznet yang sesuai dengan bentuk fluktuasi perubahan kecenderungan distribusi pendapatan dengan ukuran Koefisien Gini pertumbuhan GNP per kapita.

\subsubsection{Konsep Indeks Pembangunan Manusia}

Indeks Pembangunan Manusia menjelaskan bagaimana penduduk dapat mengakses hasil pembangunan dan memperoleh pendapatan, kesehatan, pendidikan, dan kelayakan lainnya. Menurut Todaro dan Smith (2004), salah satu keuntungan terbesar Indeks Pembangunan Manusia (IPM) adalah Indeks tersebut mengungkapkan bahwa sebuah Negara dapat berbuat jauh lebih baik pada tingkat pendapatan yang rendah dan kenaikan pendapatan yang besar dapat berperan relatif lebih kecil dalam pembangunan manusia.

\subsubsection{Konsep Investasi}

Investasi merupakan pembentukan modal untuk pembuatan pembelian, dan pengadaan barang dari dalam maupun luar negeri untuk jangka panjang. Teori Investasi Harrod-Domar menyatakan bahwa pembentukan modal/investasi merupakan faktor penting yang menentukan pertumbuhan ekonomi.Pembentukan modal tersebut dapat diperoleh melalui akumulasi tabungan. Menurut Harrod-Domar, pembentukan modal tidak hanya dipandang sebagai pengeluaran yang akan menambah kemampuan suatu perekonomian untuk menghasilkan 
barang dan jasa, tetapi juga akan meningkatkan permintaan efektif masyarakat. Investasi berpengaruh signifikan negatif terhadap ketimpangan pendapatan (Inayati, 2018)

\subsubsection{Konsep Pengeluaran Pemerintah}

Pengeluaran pemerintah merupakan suatu anggaran yang dikeluarkan pemerintah dalam melaksanakan tugasnya dan untuk kepentingan rakyatnya. Todaro (2000) menyebutkan bahwa untuk meningkatkan kesejahteraan masyarakat dan mengurangi kesenjangan pendapatan antar kelompok masyarakat, pemerintah dapat mengalokasikan anggaran yang lebih besar untuk kepentingan publik, yaitu secara langsung berupa "pembayaran transfer" dan secara tidak langsungmelalui penciptaan lapangan kerja, subsidi pendidikan, subsidi kesehatan dan lain sebagainya.

\subsubsection{Konsep Pengangguran}

Penduduk yang sedang mencari pekerjaan, penduduk yang sedang mempersiapkan suatu usaha, penduduk yang merasa tidak mungkin mendapatkan pekerjaan, penduduk yang sudahmempunyai pekerjaan tetapi belum mulai bekerja. Inayati (2018) Menyebutkan bahwa Pengangguran memiliki hubungan negatif signifikan terhadap Ketimpangan Pendapatan.

\section{Metode}

Penelitian yang dilakukan ini menggunakan jenis penelitian kuantitatif. Jenis data yang digunakan dalam penelitian ini adalah data sekunder yang berupa data panel yaitu gabungan dari data time series tahun 2015 sampai dengan tahun 2019 (5 Tahun) dan data cross section dari 32 Provinsi di Indonesia.

Teknik pengumpulan data dalam penelitian ini menggunakan teknik studi dokumenter yaitudengan mengambil data dari publikasi Badan Pusat Statistik secara nasional maupun regional yang mencakup 32 Provinsi di Indonesia. Penelitian ini menggunakan Indeks Williamson untuk mengukur disparitas pendapatan Sedangkan untuk mengukur pengaruh variabel variabel dependen terhadap variabel independen menggunakan analisis persamaan regresi data panel dengan modelRandom Effect Model (REM) melalui software Eviews10.

Indeks Williamson digunakan untuk mengetahui kondisi disparitas pendapatan di 32 provinsidi Pulau Jawa dengan rumus sebagai berikut:

$$
I W=\frac{\sqrt{\Sigma\left(Y_{i}-Y\right)^{2}} f i / n}{Y}
$$

, dimana

IW = Indeks Williamson

$\mathrm{Yi} \quad=$ PDRB kota/kabupaten

$\mathrm{Yi} \quad=\mathrm{PDB}$ provinsi

$\mathrm{Fi} \quad=$ jumlah penduduk di kota/kabupaten

$\mathrm{n} \quad=$ Jumlah penduduk di provinsi

Nilai Indeks Williamson berkisar antara 0 - 1 (positif). Semakin besar nilai indeksnya, makasemakin besar juga tingkat kesenjangan pendapatan antar wilayah. Sebaliknya, semakin kecil nilai indeksnya, maka semakin kecil pula tingkat kesenjangan yang terjadi di wilayah 
tersebut. Ketimpangan tinggi terjadi pada nilai indeks diatas 0,50. Sedangkan ketimpangan dikatakan rendahapabila nilai indeksnya dibawah 0,50.

Sedangkan untuk mengukur pengaruh variabel variabel dependen terhadap variabel independen, digunakan persamaan data panel sebagai berikut:

$$
\mathrm{Y}=\mathrm{a}+\mathrm{b}_{1} \mathrm{X}_{1}+\mathrm{b}_{2} \mathrm{X}_{2}+\mathrm{b}_{3} \mathrm{X}_{3}+\mathrm{b}_{4} \mathrm{X}_{4}+\mathrm{b}_{5} \mathrm{X}_{5}+\mathrm{e}
$$

Keterangan :

$\mathrm{Y} \quad=$ Indeks Williamson

a $=$ konstanta

b1-b7 = koefisien regresi variabel independen

$\mathrm{X}_{1} \quad=$ Pertumbuhan Ekonomi

$\mathrm{X}_{2}=\mathrm{IPM}$

$\mathrm{X}_{3} \quad=$ Investasi (PMDN)

$\mathrm{X}_{4} \quad$ = Pengeluaran Pemerintah (APBD)

$\mathrm{X}_{5} \quad=$ Tingkat Pengangguran Terbuka

Penelitian ini menggunakan beberapa uji untuk memilih model terbaik. Uji Chow digunakanuntuk memilih antara model CEM (Common Effect Model) dan dan FEM (Fixed Effect Model), sedangkan Uji Hausman dilakukan untuk memilih antara model FEM (Fixed Effect Model) dan danREM (Random Effect Model). Sementara itu, uji asumsi klasik yang dilakukan dalam penelitian iniyaitu berupa uji normalitas, uji heterokedastisitas, uji multikolinieritas, dan uji autokorelasi. Uji hipotesis yang dilakukan dalam penelitian ini yaitu Uji T untuk mengetahui pengaruh secara parsialantar masing-masing variabel bebas terhadap variabel terikat, uji yang kedua yaitu Uji F yaitu untukmengetahui ada tidaknya pengaruh bersama sama antar variabel independen terhadap variabel dependen. Lalu uji analisis Koefisien Determinasi (Adjusted R Square) untuk mengetahui besarnyapersentase pengaruh variabel independen secara keseluruhan terhadap nilai variabel dependen.

\section{Hasil dan Pembahasan}

\subsection{Disparitas Pendapatan di Indonesia}

Indonesia memiliki kondisi geografis dan tipografis yang berbeda-beda di setiap provinsinya.Hal ini menyebabkan terjadinya perbedaan pada kondisi sumber daya alam dan sumber daya manusia di setiap daerahnya. Kondisi ini juga menyebabkan terjadinya perbedaan pada disparitas pendapatan di masing-masing provinsi yang digambarkan dengan Indeks Williamson. IndeksWilliamson dari 32 provinsi di Indonesia selama 2015-2019 dapat digambarkan sebagai berikut: 


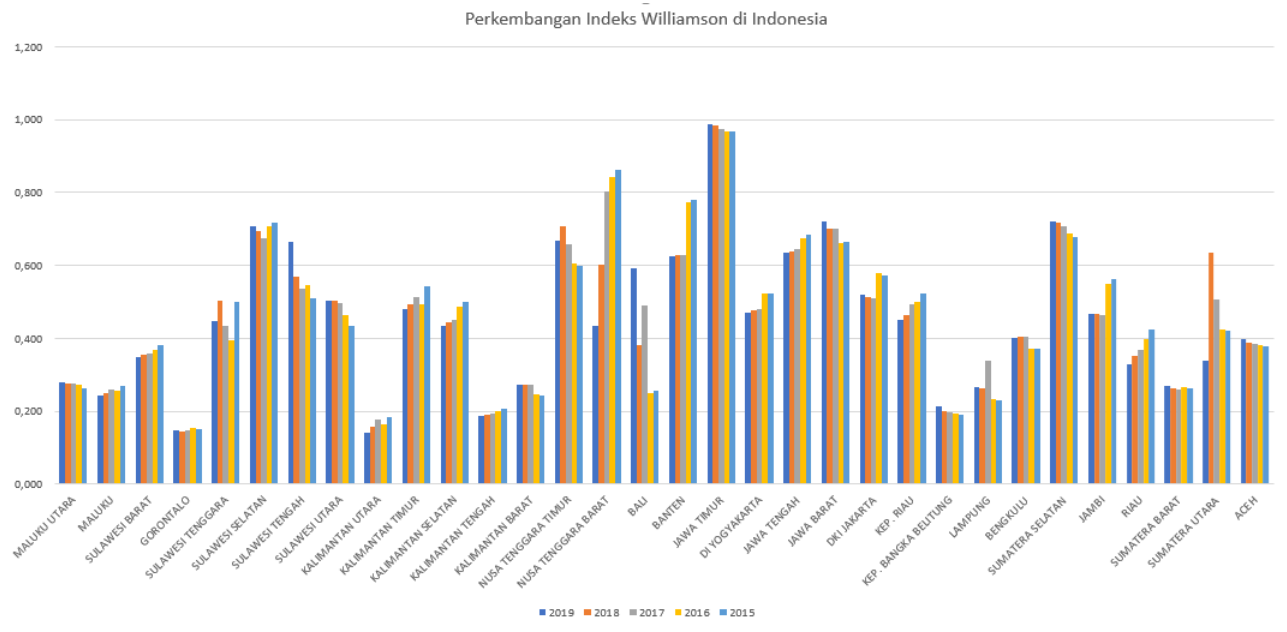

Gambar 2. Perkembangan Indeks Williamson di Indonesia 2015-2019 Sumber: Data diolah (2021)

Gambar diatas menjelaskan bahwa disparitas pendapatan tertinggi berada pada Provinsi Jawa Timur dengan rata-rata Indeks Williamson sebesar 0.976 sedangkan disparitas pendapatan terendahberada pada Provinsi Gorontalo dengan rata-rata Indeks Williamson sebesar 0.146. Dari gambar diatas dapat disimpulkan bahwa provinsi yang tergolong dalam ketimpangan rendah yaitu Provinsi Aceh, Sumatera Utara, Sumatera Barat, Riau, Bengkulu, Lampung, Kep. Bangka Belitung, Kep. Riau, DIY, Bali, Kalimantan Barat, Kalimantan Tengah, Kalimantan Utara, Sulawesi Utara, Sulawesi Tenggara, Gorontalo, Sulawesi Barat, Maluku, Maluku Utara karena memiliki rata-rata Indeks Williamson di bawah 0.5. Sedangkan provinsi yang tergolong ketimpangan tinggi yaitu Provinsi Jambi, Sumatera Selatan, DKI Jakarta, Jawa Barat, Jawa Tengah, Jawa Timur, Banten, NTB, NTT, Kalimantan Selatan, Kalimantan Timur, Sulawesi Tengah, Sulawesi Selatan karena memiliki rata-rata Indeks Williamson di atas 0.5.

\subsection{Faktor-faktor yang Mempengaruhi Disparitas Pendapatan di Pulau Jawa}

Berdasarkan estimasi data panel menggunakan eviews10, pemilihan model dilakukan melalui dua uji yaitu Uji Chow dan Uji Hausman dengan hasil seperti tabel berikut:

Tabel 1. Pemilihan Model

\begin{tabular}{llcl}
\hline Jenis Uji & Effect Test & Prob & Hasil \\
\hline Chow & CEM-FEM & 0.0000 & FEM \\
Hausman & FEM-REM & 0.0950 & REM \\
\hline
\end{tabular}

Sumber: Data diolah (2021)

Berdasarkan Uji Chow nilai dari Prob Cross Section chi square sebesar 0,0000 yang artinyakurang dari 0.05 atau 5\%, maka model FEM lebih sesuai digunakan dalam penelitian ini. Berdasarkan Uji Hausman nilai dari Prob Cross Section chi square sebesar 0.0950 yang artinya kurang dari 0.05 atau 5\%, maka model REM lebih sesuai digunakan dalam penelitian ini. 
Dari kedua uji diatas dapat disimpulkan bahwa model REM merupakan model terbaik dari penelitian ini. Dengan model REM, hasil analisis regresi yang diperoleh adalah sebagai berikut:

Tabel 2. Analisis Hasil Regresi Menggunakan REM

\begin{tabular}{lll}
\hline \multicolumn{1}{c}{ Variable } & Coefficient & Probability \\
\hline Pertumbuhan & 0.011500 & 0.1558 \\
IPM & -0.013055 & 0.0082 \\
Log_Investasi & 0.009692 & 0.4570 \\
Log_Apbd & 0.295365 & 0.0000 \\
TPT & 0.014168 & 0.0257 \\
C & -0.764979 & 0.0429 \\
R Square & & 0.236103 \\
Adjusted R- & & 0.211301 \\
Square & & \\
F-Statistic & & 9.519589 \\
Prob (F- & & 0.000000 \\
Statistic) & & \\
Sumber: Data diolah (2021) &
\end{tabular}

Sehingga dapat diperoleh model persamaan sebagai berikut:

$Y=-0.764979+0.011500 X 1-0.013055 X 2+0.009692 X 3+0.295365 X 4+0.014168 X 5+e$

Dari data diatas dapat dilihat regresi data panel menggunakan Random Effect Model (REM) dan didapatkan hasil bahwa Indeks Williamson memiliki koefisien negatif sebesar 0.764979 yang artinya apabila Pertumbuhan Ekonomi, IPM, Investasi, APBD, dan TPT bernilai nol (0) maka Indeks Williamson bernilai -0.764979 \%. Pertumbuhan Ekonomi memiliki hubungan positif dan memiliki pengaruh signifikan terhadap disparitas pendapatan pada tingkat alpha 20\%, apabila Pertumbuhan Ekonomi mengalami kenaikan sebesar 1\% maka Indeks Williamson juga mengalami kenaikan sebesar $0.011500 \%$ dan sebaliknya. IPM memiliki hubungan negatif signifikan pada tingkat signifikansi 5\%, jika IPM mengalami kenaikan sebesar $1 \%$ maka Indeks Williamson mengalami penurunan sebesar $0.013055 \%$ dan sebaliknya. Investasi memiliki hubungan positif dan memiliki pengaruh signifikan terhadap disparitas pendapatan pada tingkat alpha 50\%, apabila Investasi mengalami kenaikan sebesar $1 \%$ maka Indeks Williamson juga mengalami kenaikan sebesar $0.009692 \%$ dan sebaliknya. APBD memiliki hubungan positif dan memiliki pengaruh signifikan terhadap disparitas pendapatan pada tingkat alpha 5\%, sehingga jika APBD mengalami kenaikan sebesar $1 \%$ maka Indeks Williamson juga mengalami kenaikan sebesar $0.295365 \%$ dan sebaliknya.Lalu TPT memiliki hubungan positif dan memiliki pengaruh signifikan terhadap disparitas pendapatan pada tingkat alpha 5\%, sehingga jika TPT mengalami kenaikan sebesar $1 \%$ maka Indeks Williamson juga mengalami kenaikan sebesar $0.014168 \%$ dan sebaliknya.

Uji T mengindikasikan bahwa Pertumbuhan Ekonomi tidak berpengaruh signifikan terhadapIndeks Williamson karena nilai probabilitasnya lebih dari 0.05 atau 5\%. Lalu, variabel IPM memiliki probabilitas sebesar 0.0082, sehingga dapat diartikan bahwa IPM berpengaruh signifikan terhadapIndeks Williamson karena nilai probabilitasnya kurang dari 0.05 atau 5\%. Kemudian untuk variabel Investasi memiliki probabilitas sebesar 0.4570 , sehingga dapat diartikan bahwa Investasi tidak berpengaruh signifikan terhadap Indeks Williamson karena nilai probabilitasnya lebih dari 0.05 atau 5\%. Sedangkan untuk variabel APBD memiliki 
probabilitas sebesar 0.0000, sehingga dapatdiartikan bahwa APBD berpengaruh signifikan terhadap Indeks Williamson karena nilai probabilitasnya kurang dari 0.05 atau 5\%. Dan untuk variabel TPT memiliki probabilitas sebesar 0.0257 , sehingga dapat diartikan bahwa TPT tidak berpengaruh signifikan terhadap Indeks Williamson karena nilai probabilitasnya lebih dari 0.05 atau $5 \%$.

Berdasarkan tabel diatas dapat diketahui bahwa nilai F-hitung 9.519589 dengan probabilitas 0.000000. sehingga dapat diartikan bahwa secara simultan Pertumbuhan Ekonomi, IPM, Investasi, APBD dan TPT berpengaruh secara signifikan terhadap Indeks Williamson, karena nilai probabilitasnya lebih kecil dari 0.05 atau 5\%. Lalu berdasarkan Uji Koefisien Determinasi, nilai $\mathrm{R}^{2}$ dalam penelitian ini sebesar 0.236103 . Hal ini berarti bahwa etase nilai tukar yang dapat dijelaskanoleh variabel independen adalah sebesar $23 \%$ dan sisanya (100\%-23\%) 77\% dijelaskan oleh variabel lain diluar model.

Uji Asumsi Klasik yang digunakan untuk mengetahui apakah penelitian ini layak atau tidakdigunakan adalah residual menyebar normal (uji normalitas), antar residual saling bebas (uji autokorelasi), dan kehomogenan ragam residual (uji heterokedastisitas), dan antar variabel independen tidak berkorelasi (uji multikolinieritas). Hasil dari uji asumsi klasik dalam penelitian iniadalah sebagai berikut:

\subsubsection{Uji Normalitas}

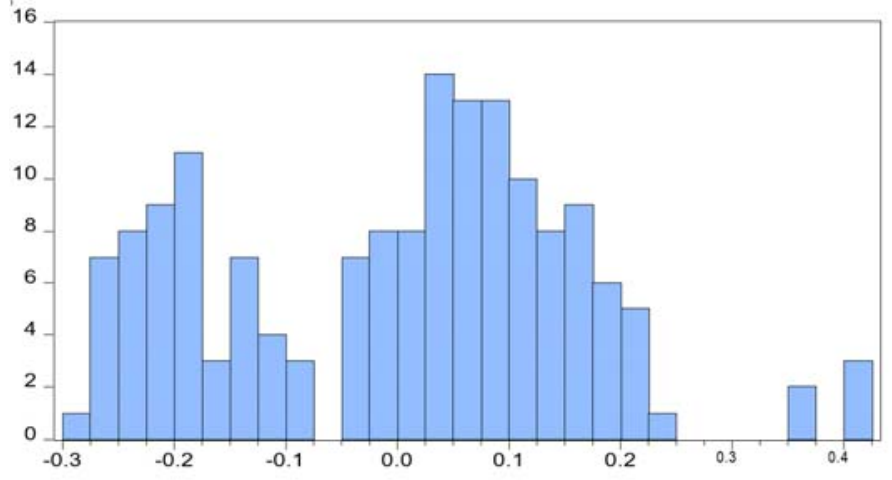

$\begin{array}{ll}\text { Series: Standardized Residuals } \\ \text { Sample } 20152019 \\ \text { Observations } & 160 \\ & \\ \text { Mean } & 7.68 \mathrm{e}-16 \\ \text { Median } & 0.029566 \\ \text { Maximum } & 0.417071 \\ \text { Minimum } & -0.276169 \\ \text { Std. Dev. } & 0.158490 \\ \text { Skewness } & 0.052706 \\ \text { Kurtosis } & 2.480988 \\ & \\ \text { Jarque-Bera } & 1.869904 \\ \text { Probability } & 0.392605\end{array}$

Gambar 3. Grafik Jarque Bera

Dari grafik diatas dapat dilihat hasil dari Jarque Bera memiliki nilai sebesar 1.869904 dan nilai probabilitas sebesar 0.392605 . Penelitian ini dikatakan berdistribusi normal karena memiliki nilai probabilitas dibawah 0,05 atau $5 \%$.

\subsubsection{Uji Heterokedastisitas}

Tabel 3. Uji Heterokedastisitas

\begin{tabular}{llllc}
\hline \multicolumn{1}{c}{ Variable } & Coefficient & \multicolumn{1}{c}{ Std. Error } & \multicolumn{1}{c}{ t-Statistic } & Prob. \\
\hline C & 0.463339 & 0.266096 & 1.741250 & 0.0836 \\
PERTUMBUHAN & 0.009640 & 0.006190 & 1.557268 & 0.1215 \\
IPM & -0.004277 & 0.003314 & -1.290786 & 0.1987 \\
LOG_INVESTASI & 0.005556 & 0.010035 & 0.553728 & 0.5806 \\
LOG_APBD & -0.013376 & 0.033073 & -0.404429 & 0.6865
\end{tabular}




\begin{tabular}{llllr}
\hline Variable & Coefficient & Std. Error & t-Statistic & Prob. \\
\hline TPT & -0.002653 & 0.004587 & -0.578532 & 0.5638 \\
\hline
\end{tabular}

Dari tabel diatas dapat diketahui bahwa pada semua variabel tidak terdapat gejala heterokedastisitas karena nilai probabilitas pada setiap variabel independen memiliki diatas 0,05 atau $5 \%$.

\subsubsection{Uji Multikolinieritas}

Tabel 4. Uji Multikolinearitas

\begin{tabular}{llllll}
\hline \multicolumn{2}{c}{ PERTUMBUHAN } & \multicolumn{3}{c}{ LOG_INVES } & \\
& & IPM & TASI & LOG_APBD & TPT \\
\hline PERTUMBUHAN & 1.000000 & - & -0.186539 & 0.014036 & -0.263581 \\
& & 0.093109 & & & \\
IPM & -0.093109 & 1.000000 & 0.317454 & 0.268679 & 0.230905 \\
LOG_INVESTASI & -0.186539 & 0.317454 & 1.000000 & 0.619933 & 0.224305 \\
LOG_APBD & 0.014036 & 0.268679 & 0.619933 & 1.000000 & 0.089796 \\
LOG_TPAK & -0.263581 & 0.230905 & 0.224305 & 0.089796 & 1.000000 \\
\hline
\end{tabular}

Dari tabel diatas dapat diketahui bahwa koefisien korelasi antar variabel independen yang diteliti memiliki nilai yang kurang dari 0.85. maka dari itu dapat disimpulkan bahwa tidak terjadi gejala multikolinieritas antar variabel independen dalam penelitian.

\subsubsection{Uji Autokorelasi}

Pada tabel model REM, menjelaskan nilai Durbin Watson sebesar 2.022065 sehingga dapat dijelaskan area auto korelasi dengan gambar sebagai berikut:

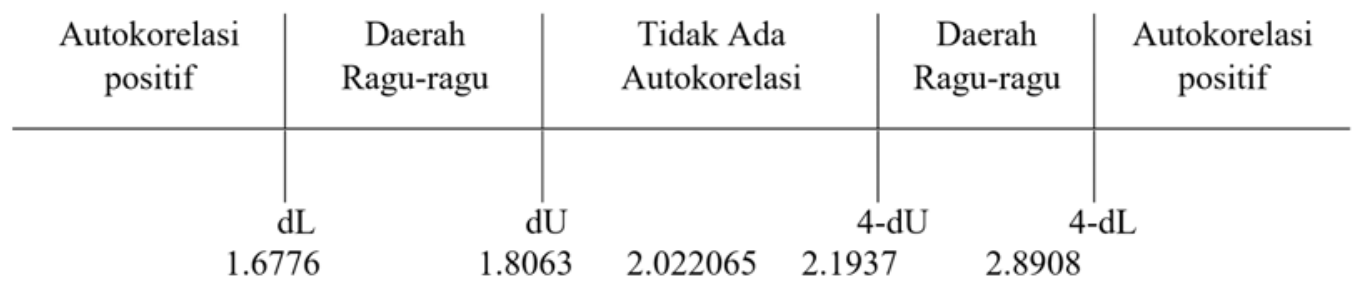

Gambar 4. Model REM

Dari gambar diatas dapat disimpulkan bahwa model regresi tidak terdapat gejala autokorelasi karena hasil Drubin Watson berada pada titik "tidak ada Autokorelasi" danberada diantara titik dU dan 4-dU.

\subsection{Pengaruh Pertumbuhan Ekonomi terhadap Disparitas Pendapatan di Pulau Jawa}

Pertumbuhan Ekonomi memiliki hubungan positif dan memiliki pengaruh signifikan terhadap disparitas pendapatan pada tingkat alpha 20\%, apabila Pertumbuhan Ekonomi mengalamikenaikan sebesar 1\% maka Indeks Williamson juga mengalami kenaikan sebesar $0.011500 \%$ dan sebaliknya. 
Meningkatnya pertumbuhan ekonomi yang diikuti dengan meningkatnya ketimpangan pendapatan di Indonesia dapat terjadi karena dalam jangka pendek hasil dari keberhasilan pembangunan belum bisa dirasakan oleh keseluruhan masyarakat Indonesia. Hal ini dikarenakan pemerataan pembangunan dalam kurun waktu 2015 hingga 2019 masih pada tahap awal sehingga belum dapat berpengaruh terhadap disparitas pendapatan. Waktu penelitian yang tidak terlalu lama ini pula yang menyebabkan hasil dari pengaruh pertumbuhan penduduk terhadap disparitas pendapatan tidak signifikan. Di sisi lain, dalam jangka panjang pertumbuhan ekonomi akan berpengaruh negatif terhadap disparitas pendapatan. Menurunnya disparitas pendapatan ini dikarenakan dalam jangka panjang, pertumbuhan ekonomi akan dapat dirasakan masyarakat secaraoptimal dan menyeluruh. Hal ini sesuai dengan teori Kuznet bahwa pertumbuhan ekonomi dalam jangka pendek akan memperburuk pemerataan pendapatan, namun pada tahap selanjutnya pemerataan pendapatan akan membaik seiring meningkatnya pertumbuhan ekonomi. Teori ini sering dikenal dengan hipotesis "U terbalik" Kuznet. Dengan begitu dapat disimpulkan bahwa tahap awal hipotesis " $U$ terbalik" berlaku pada hubungan pertumbuhan ekonomi dan disparitas di Indonesia tahun 2015-2019.

Hasil yang menyebutkan bahwa meningkatnya pertumbuhan ekonomi akan meningkatkan Disparitas Pendapatan ini sesuai dengan penelitian yang dilakukan oleh Masuri (2014) dalam penelitiannya yang berjudul "Analisis Pengaruh Pertumbuhan Ekonomi, Ipm,Tpak Dan Pengangguran Terbuka Terhadap Ketimpangan Pendapatan Antar Daerah Di Provinsi Jawa TengahTahun 2011-2014"

\subsection{Pengaruh IPM (Indeks Pembangunan Manusia) terhadap Disparitas Pendapatan di Pulau Jawa}

IPM memiliki hubungan negatif signifikan pada tingkat signifikansi 5\%, jika IPM mengalamikenaikan sebesar $1 \%$ maka Indeks Williamson mengalami penurunan sebesar $0.013055 \%$ dan sebaliknya.

Indeks Pembangunan Manusia (IPM) merupakan suatu indeks yang menggambarkan kesehatan, pendidikan, dan pengeluaran. Jika ketiga komponen tersebut meningkat maka akan meningkatkan kualitas sumber daya manusia secara keseluruhan. Kualitas sumber daya manusia yang tinggi akan meningkatkan produktivitas masyarakat sehingga akan menurunkan disparitas pendapatan. Karena pada dasarnya pembangunan manusia yang baik akan memperbaiki pula tingkatpendidikan, kesehatan, dan pengeluaran masyarakat. Di sisi lain, semakin tinggi pendidikan formalyang diperoleh suatu masyarakat, maka produktivitas tenaga kerja akan semakin tinggi pula. Hal tersebut sesuai dengan teori human capital, yaitu bahwa pendidikan memiliki pengaruh terhadap pertumbuhan ekonomi dan akan mengurangi disparitas pendapatan dikarenakan pendidikan berperan di dalam meningkatkan produktivitas tenaga kerja. Teori tersebut menganggap pertumbuhan penduduk dapat ditentukan oleh produktivitas kerja perorangan. Jika setiap orang memiliki pendapatan yang lebih tinggi karena pendidikannya lebih tinggi, maka pertumbuhan ekonomi penduduk dapat ditunjang, dengan adanya pertumbuhan ekonomi baik secara langsung maupun tidak langsung akan berpengaruh negatif terhadap ketimpangan pendapatan.

Hasil yang menyebutkan bahwa IPM akan menurunkan Disparitas Pendapatan ini sesuai dengan teori yang dikemukakan oleh Todaro and Smith yang menyebutkan bahwa terdapat 
faktor faktor yang dapat menanggulangi kesenjangan seperti kesehatan dan pendidikan. Hasil penelitian ini juga sesuai dengan hasil penelitian yang dilakukan oleh Masruri (2016) dalam penelitiannya yang berjudul "Analisis Pengaruh Pertumbuhan Ekonomi, Ipm,Tpak Dan Pengangguran Terbuka Terhadap Ketimpangan Pendapatan Antar Daerah Di Provinsi Jawa Tengah Tahun 2011-2014"

\subsection{Pengaruh Investasi (PMDN) terhadap Disparitas Pendapatan di Pulau Jawa}

Investasi memiliki hubungan positif dan memiliki pengaruh signifikan terhadap disparitas pendapatan pada tingkat alpha 50\%, apabila Investasi mengalami kenaikan sebesar $1 \%$ maka Indeks Williamson juga mengalami kenaikan sebesar $0.009692 \%$ dan sebaliknya.

Investasi merupakan pengeluaran atau perbelanjaan para penanam modal atau perusahaan untuk membeli barang-barang modal dan perlengkapan-perlengkapan produksi untuk menambah kemampuan memproduksi barang dan jasa yang tersedia dalam perekonomian, sehingga investasi disebut juga dengan penanaman modal (Sukirno, 2016). Meningkatnya Investasi yang diikuti dengan meningkatnya ketimpangan pendapatan di pulau Jawa dapat terjadi karena di Pulau Jawa para investor dalam menanamkan modalnya tidak memperhatikan bagaimana pendistribusian pendapatan dikalangan masyarakat. Dalam melakukan investasi, para investor hanya mempertimbangkan pembangunan infrastruktur, potensi daerah dan hal hal yang mendukung kepentingan investasi. Para investor juga akan memilih daerah daerah maju atau daerah berpotensi sehingga pada daerah yang tidak berpotensi tidak terjamah oleh para investor dan investasi hanya terkonsentrasi pada daerah tertentu saja. Hubungan positif antara investasi dan disparitas pendapatanini juga dipengaruhi oleh alokasi investasi yang tidak merata pada provinsi-provinsi di Pulau Jawa sehingga berdampak pada pemusatan investasi pada suatu daerah dan menyebabkan pada kesenjangan pendapatan masyarakat antara daerah yang mendapatkan penanaman modal tinggi dan rendah.

Hasil yang menyebutkan bahwa investasi akan meningkatkan Disparitas Pendapatan ini sesuai dengan teori yang dikemukakan oleh Harrod-Domar dalam Haris Hidayat (2014) dalam penelitiannya yang berjudul "Analisis Pengaruh Pertumbuhan Ekonomi, Investasi, Dan Ipm Terhadap Ketimpangan Pendapatan Antar Daerah Di Provinsi Jawa Tengah Tahun 2005-2012“ yang menyebutkan bahwa investasi akan berpengaruh secara langsung ataupun tidak langsung pada pertumbuhan ekonomi dan seiring dengan peningkatan pertumbuhan tersebut maka akan berpengaruh pada ketimpangan pendapatan. Namun berbanding terbalik dengan penelitian dari Inayati (2018) yang berjudul "The Corruption Income and Inequality Trap" yang menyebutkan bahwa FDI mampu menurunkan ketimpangan pendapatan.

\subsection{Pengaruh Pengeluaran Pemerintah (APBD) terhadap Disparitas Pendapatan di Pulau Jawa}

APBD (Anggaran Pendapatan dan Belanja Daerah) merupakan salah satu bentuk pengeluaran pemerintah yang mana menurut Todaro pengeluaran pemerintah bertujuan untuk meningkatkan kesejahteraan masyarakat dan mengurangi kesenjangan pendapatan antar kelompok masyarakat. APBD memiliki hubungan positif dan memiliki pengaruh signifikan terhadap disparitas pendapatan pada tingkat alpha 5\%, sehingga jika APBD 
mengalami kenaikan sebesar $1 \%$ maka Indeks Williamson juga mengalami kenaikan sebesar $0.295365 \%$ dan sebaliknya.

Namun pernyataan Todaro berbanding terbalik dengan hasil dari penelitian ini. Meningkatnya APBD (Anggaran Pendapatan dan Belanja Daerah) yang diikuti dengan meningkatnya ketimpangan pendapatan di Pulau Jawa dapat terjadi karena pengeluaran pemerintah yang disalurkan ke masyarakat belum secara sepenuhnya dapat dinikmati dan dijangkau oleh seluruh lapisan masyarakat. Penguasaan anggaran oleh hanya beberapa kelompok saja menjadikan tingginya APBD (Anggaran Pendapatan dan Belanja Daerah) menjadi faktor penyebab tingginya disparitas pendapatan. Hal ini mengartikan bahwa pengeluaran pemerintah belum mampu menekan tingkat disparitas pendapatan di Pulau Jawa. Padahal, tujuan dari pengeluaran pemerintah sendiri sebenarnya merupakan stimulus untuk mencapai kesejahteraan dan pemerataan pendapatan di PulauJawa. Selain itu, permasalahan alokasi anggaran APBD menjadi suatu hal yang perlu diperhatikan mengingat besarnya pengeluaran pemerintah untuk setiap daerah tidak sama. Strategi alokasi pengeluaran pemerintah tersebut perlu dilaksanakan dengan tepat agar dapat menstimulus dan mempercepat pertumbuhan ekonomi dan mengurangi disparitas pendapatan antar daerah. Dalam penelitian ini, pengeluaran pemerintah yang menjadi salah satu penyebab disparitas pendapatan diasumsikan sebagai pengeluaran pemerintah yang semakin tinggi, terpusat, namun tidak merata. Pengeluaran pemerintah pada setiap daerah memiliki besaran yang tidak sama karena menyesuaikandengan kondisi daerah yang berbeda-beda baik dari jumlah penduduk maupun pendapatan asli daerahnya. Maka dari itu rumusan alokasi pengeluaran pemerintah untuk setiap daerah perlu dilakukan dengan baik agar permasalahan disparitas pendapatan dapat diperbaiki.

Hasil yang menyebutkan bahwa pengeluaran pemerintah akan menurunkan Disparitas Pendapatan ini berbanding terbalik dengan teori yang dikemukakan oleh Todaro (2000) yang menyebutkan bahwa anggaran pemerintah mampu meningkatkan kesejahteraan masyarakat dan mengurangi kesenjangan. Teori ini tidak berlaku pada disparitas di Indonesia karena dalam penelitian ini rentan waktu yang digunakan relatif singkat yakni tahun 20152019 sedangkan pemerataan pendapatan yang disebabkan oleh pengeluaran pemerintah memerlukan proses dan jangka waktu yang panjang. Hasil penelitian ini juga berbanding terbalik dengan penelitian dari Inayati (2018) yang berjudul "The Corruption Income and Inequality Trap" yang menyebutkan bahwa Pengeluaran pemerintah mampu menurunkan ketimpangan pendapatan. Hubungan signifikan positif antara pengeluaran pemerintah dan disparitas pendapatan ini sesuai dengan penelitian yang dilakukan oleh I Gusti Ayu Wahyuni (2014) dalam penelitiannya yang berjudul "Pengaruh Pengeluaran Pemerintah Dan Investasi Terhadap Pertumbuhan Ekonomi Dan Kesenjangan Pendapatan Kabupaten/Kota Di Provinsi Bali"

\subsection{Pengaruh TPT (Tingkat Pengangguran Terbuka) terhadap Disparitas Pendapatan di Pulau Jawa}

Lalu TPT memiliki hubungan positif dan memiliki pengaruh signifikan terhadap disparitas pendapatan pada tingkat alpha 5\%, sehingga jika TPT mengalami kenaikan sebesar $1 \%$ maka Indeks Williamson juga mengalami kenaikan sebesar $0.014168 \%$ dan sebaliknya. 
Tingkat Pengangguran Terbuka merupakan persentase jumlah pengangguran terhadap jumlah angkatan kerja. Namun, lapangan pekerjaan di daerah perkotaan masih kurang bisa menampung jumlah pengangguran di Indonesia sehingga tingkat pengangguran di Indonesia semakintahun semakin meningkat. Apabila tingkat pengangguran berkurang dengan asumsi bahwa semakin banyak penduduk yang bekerja, maka produktivitas semakin meningkat sehingga pendapatan juga meningkat dan menyebabkan ketimpangan juga berkurang. Semakin meningkatnya jumlah masyarakat yang bekerja dan menerima pendapatan diharapkan mampu memperkecil ketimpangandistribusi pendapatan yang ada Di Indonesia. Permasalahan pengangguran yang disebabkan oleh berkurangnya lapangan pekerjaan dapat dikurangi dengan mencanangkan pelatihan pelatihan kewirausahaan padat karya untuk menstimulus agar masyarakat termotivasi untuk berwirausaha sehingga lapangan pekerjaan bertambah.

Hasil yang menyebutkan bahwa TPT (Tingkat Pengangguran Terbuka) akan meningkatkanDisparitas Pendapatan ini sesuai dengan penelitian Sabda Imani R. Dkk(2013) yang berjudul "Analisis Faktor-Faktor Yang Mempengaruhi Disparitas Pendapatan Di Provinsi Jawa Timur Tahun2008-2011”.

\section{Simpulan}

Dari analisis yang telah dilakukan peneliti Kondisi disparitas pendapatan di 32 provinsi di Indonesia dalam periode 2015-2019 sangat beragam dan fluktuatif. Disparitas pendapatan tertinggidimiliki oleh Provinsi Jawa Timur dengan nilai rata-rata Indeks Williamson sebesar 0.976, sedangkan untuk provinsi yang memiliki disparitas pendapatan paling rendah yaitu Gorontalo dengan rata-rata Indeks Williamson sebesar 0.149. Dari tabel diatas dapat disimpulkan bahwa provinsi yang tergolong dalam ketimpangan rendah yaitu Provinsi Aceh, Sumatera Utara, SumateraBarat, Riau, Bengkulu, Lampung, Kep. Bangka Belitung, Kep. Riau, DIY, Bali, Kalimantan Barat,Kalimantan Tengah, Kalimantan Utara, Sulawesi Utara, Sulawesi Tenggara, Gorontalo, Sulawesi Barat, Maluku, Maluku Utara. Sedangkan provinsi yang tergolong ketimpangan tinggi yaitu Provinsi Jambi, Sumatera Selatan, DKI Jakarta, Jawa Barat, Jawa Tengah, Jawa Timur, Banten, NTB, NTT, Kalimantan Selatan, Kalimantan Timur, Sulawesi Tengah, Sulawesi Selatan.

Faktor faktor yang berpengaruh positif terhadap disparitas pendapatan yakni pertumbuhan ekonomi, investasi, APBD, dan TPT. Sedangkan faktor yang berpengaruh negatif yakni IPM. Variabel yang berpengaruh signifikan pada tingkat alpha 5\% yakni Indeks Pembangunan Manusia, APBD, dan TPT karena memiliki Prob dibawah 0.05 atau 5\% sedangkan variabel pertumbuhan ekonomi memiliki prob sebesar 0.1558 sehingga berpengaruh signifikan terhadap disparitas pendapatan pada tingkat alpha 0.2 atau $20 \%$, dan investasi memiliki prob sebesar 0.4570 sehingga berpengaruh signifikan pada tingkat alpha 0.5 atau $50 \%$.

Berdasarkan studi yang dilakukan dalam penelitian ini, maka terdapat beberapa saran yang dapat dijadikan bahan pertimbangan bagi pihak yang bersangkutan dan bagi peneliti selanjutnya. Bagi pemerintah diharapkan mampu mengontrol laju pertumbuhan ekonomi dan IPM agar kualitassumber daya manusia dan perekonomian Indonesia tetap terjaga dengan baik. Seharusnya pemerintah juga memperhatikan alokasi PMDN dan APBD agar antar daerah tidak mengalami kesenjangan yang semakin parah. Pemerintah diharapkan juga mampu mengeluarkan regulasi mengenai urbanisasi, pelatihan kewirausahaan padat karya, serta 
membuka lapangan pekerjaan baru agar pengangguran di Indonesia dapat berkurang. Selain itu, peneliti selanjutnya diharapkan mampumenggunakan objek penelitian yang berbeda dan lebih komprehensif.

\section{Daftar Rujukan}

Ani, N. (2017). Analisis Faktor-Faktor Yang Mempengaruhi Ketimpangan Distribusi Pendapatan DiPulau Jawa Tahun 2007-2013. Yogyakarta: UNY

Ariza, I. \& Atwal, A. (2017). Pengaruh Pengeluaran Pemerintah Dan Investasi Terhadap Kesenjangan Pendapatan Dengan Pertumbuhan Ekonomi Sebagai Variabel Intervening Studi Empiris Pada Provinsi Se-Sumatera Tahun 2011-2014. Surakarta: Universitas Muhammadiyah Surakarta

Budiantoro, H. (2008). Analisis Ketimpangan Pembangunan Ekonomi di Provinsi Jawa Tengah. Semarang: Universitas Diponegoro

Danawati, S., Bendesa, I. K. G., \& Utama, M. S. (2016). Pengaruh Pengeluaran Pemerintah Dan Investasi Terhadap Kesempatan Kerja, Pertumbuhan Ekonomi Serta Ketimpangan Pendapatan Kabupaten/Kota Di Provinsi Bali. E-Jurnal Ekonomi dan Bisnis Universitas Udayana, 5(7), 2123-2160.

Darzal, D. (2016). Analisis Disparitas Pendapatan Dan Faktor-Faktor Yang Mempengaruhinya Di Provinsi Jambi. Jurnal Perspektif Pembiayaan Dan Pembangunan Daerah, 4(2), 131-142.

Distraniati Fadhila Desthy. (2020). Analisis Faktor-Faktor Yang Mempengaruhi Disparitas Pendapatan Di Provinsi Jawa Barat. Surakarta: UMS

Dwiputri, Inayati Nuraini. (2018). The Corruption-income Inequality Trap: A Study of Asian Countries. Malang: Economics Discussion Papers

DWIPUTRI, I. N., PRADIPTYO, R., \& ARSYAD, L. (2019). Corruption and Capital Growth: Identification of Bribery by the Firm. International Journal of Economics \& Management, 13(2).

Estudillo, J. P. (1997). Income inequality in the Philippines, 1961-91. The Developing Economies, 35(1), 68-95.

Herzer, D., \& Nunnenkamp, P. (2011). FDI and income inequality: Evidence from Europe (No. 1675). Kiel working paper.

Hidayat, Mohammad Haris. (2014). Analisis Pengaruh Pertumbuhan Ekonomi, Investasi, Dan IPM Terhadap Ketimpangan Pendapatan Antar Daerah Di Provinsi Jawa Tengah Tahun 2005- 2012. Semarang: Universitas Dipenogoro.

Vo, D. H., Nguyen, T. C., \& Tran, N. P. (2019). What factors affect income inequality and economic growth in middle-income countries?. Journal of Risk and Financial Management, 12(1), 40.

I Gusti Ayu Putri Wahyuni,Dkk. (2014). Pengaruh Pengeluaran Pemerintah Dan Investasi TerhadapPertumbuhan Ekonomi Dan Kesenjangan Pendapatan Kabupaten/Kota Di Provinsi Bali. Bali : Universitas Udayana. EJurnal Ekonomi dan Bisnis Universitas Udayana, 3, 44700.

Kuznets S. (1955). Economic Growth And Income Inequality. The American Economic Review. Vol45, Issue 1 (Mar.,1955), 1-28. Amerika Serikat (AS): JSTOR.

Lilis Setyowati Dan Yohana Kus Suparwati. (2012). Pengaruh Pertumbuhan Ekonomi, DAU, DAK, PAD Terhadap Indeks Pembangunan Manusia Dengan Pengalokasian Anggaran Belanja Modal Sebagai Variabel Intervening. Jurnal Prestasi, 9(1), 113-133.

Lincolin Arsyad. (1999). Pengantar Perencanaan Dan Pembangunan Ekonomi Daerah. BPFE UGM. Yogyakarta

Masruri, M. (2016). Analisis Pengaruh Pertumbuhan Ekonomi, Ipm, Tpak Dan Pengangguran Terbuka Terhadap Ketimpangan Pendapatan Antar Daerah Di Provinsi Jawa Tengah Tahun 2011-2014. Jurnal Ilmiah Mahasiswa FEB, 5(1).

Mawardi I, (1997). Daya Saing Kawasan Timur Indonesia Dan Kawasan Pengembangan Ekonomi Terpadu.Prisma08. Hal 51-61

Sari, P. I. M., Mulatsih, S., \& Fahmi, I. (2014). Income Distribution Inequality in West Sumatera and The Related Factors. Jurnal Ekonomi dan Kebijakan Pembangunan, 3(1), 1-7.

Mudrajat Kuncoro. (1997). Ekonomi Pembangunan: Teori, Masalah, Dan Kebijakan. YKPN. Yogyakarta 
Nubuo Akai, Dkk. (2005). Fiscal Decentralization, Commitment And Regional Inequality: Evience From State Level Cross Sectional Data From United States. Osaka: University of Hyogo and Osaka International University

Reza. (2018). Analisis Faktor-Faktor Yang Mempengaruhi Ketimpangan Pendapatan Di Indonesia (Periode 2011 2016). Malang: Universitas Brawijaya

Rubiarko, S. I., \& Sakti, R. K. (2012). Analisis Faktor-Faktor yang Mempengaruhi Disparitas Pendapatan di Provinsi Jawa Timur Tahun 2008-2011. Jurnal Ilmiah Mahasiswa FEB, 1(2).

Perencanaan, B. (2014). Rencana Pembangunan Jangka Menengah Nasional Republik Indonesia (RPJMNRI) 2015-2019 pemerintah. Jakarta: Bappenas.

Simanjuntak, Payaman J. (1985). Pengantar Ekonomi Sumber Daya Manusia. Jakarta: Andi Edisi Pertama.

Sugiyono. (2013). Metode Penelitian Pendidikan: Pendekatan Kuantitatif, Kualitatif, Dan R\&D. Bandung: CV. Alfabeta.

Sukirno, S. (2016). Ekonomi Pembangunan, Proses, masalah dan dasar kebijakan, Edisi Pertama. Jakarta: LPFE UI Bima Grafika.

Sukirno, Sadono. (1978). Ekonomi Pembangunan: Proses, Masalah, Dan Dasar Kebijakan, Medan:Borta

Sukirno. (2002). Ekonomi Pembangunan. Jakarta: Lembaga Penerbit Fakultas Ekonomi UniversitasIndonesia.

Sulistyowati Risma Gilang. (2018). Analisis Disparitas Pendapatan Di Indonesia Tahun 2010-2016. Surakarta:UMS

Sjafrizal, S. (1997). Pertumbuhan ekonomi dan ketimpangan regional wilayah Indonesia Bagian Barat. Jurnal Buletin Prisma, 3(3), 27-38.

Todaro, M.P. (2000). Pembangunan Ekonomi Di Dunia Ketiga. Jakarta: Erlangga Todaro, Michael. 2006. Pembangunan Ekonomi Jilid 2, Jakarta: Erlangga

Todaro, Michael.P. Dan Stephen C. Smith. (2004). Pembangunan Ekonomi Di Dunia Ketiga, EdisiKedelapan. Jakarta: Penerbit Erlangga. 